Wange Mangala Dilip / Int. J. Res. Ayurveda Pharm. 4(4), Jul-Aug 2013

Research Article

www.ijrap.net

\title{
IMPORTANCE OF AGNI (DIGESTIVE FIRE) IN THE MANAGEMENT OF GRAHANI DISEASE WITH SPECIAL REFERENCE TO LAVANBHASKARCHURNA IN GRAHANIROGA (SMALL INTESTINE DISEASE)
}

Wange Mangala Dilip*

Dr. D.Y. Patil, College of Ayurved and Research Institute, Nerul, Navi Mumbai, Maharashtra, India

Received on: 09/05/13 Revised on: 16/06/13 Accepted on: 12/07/13

\author{
*Corresponding author \\ E-mail: mangalawange@gmail.com \\ DOI: $10.7897 / 2277-4343.04426$ \\ Published by Moksha Publishing House. Website www.mokshaph.com \\ All rights reserved.
}

\section{ABSTRACT}

The aim of this study is to see the effect of Lavanbhaskar churna in Grahaniroga (Small intestine disease). An uncontrolled, open label clinical study was done on 15 patients of Grahaniroga (Small intestine disease). Lavanbhaskar churna 1-3 g twice a day as an Agnideepan (stimulating digestion) was given to patient after their enrolment in study. Assessment of signs such as Agnimandya (suppressed digestive fire), Aruchi (loss of taste), Trushna (thirst), Chardi (vomiting), Adhmana (distension), randomly loose or hard stool (Asamyak mal pravrutti) was assessed. Every patient assessed for any clinical improvement and for adverse effects regularly, follow-up taken at every week for 2 month. Improvement in condition was recorded as shifting of gradation in signs of Grahaniroga (Small intestine disease). Clinical study has shown symptomatic improvement in Grahaniroga (Small intestine disease). This indicates that the effect of drug is extremely significant in the Grahaniroga (Small intestine disease) as an Agnideepan (stimulating digestion).

Keywords: Grahaniroga (Small intestine disease), Lavanbhaskar churna, Agnideepan (stimulating digestion), Importance of Agni chikitsa (digestive fire treatment).

\section{INTRODUCTION}

Today is the era of science, in which everyone is busy to get luxurious life style. Due to development of science many pesticides and chemicals are used to increase productivity. Polluted air and water lead to many disease of Annavahastrotasa (digestive system). The faulty life style lead to interruption of Dincharya (daily regimen) and Ritucharya (seasonal regimen), described in Ayurveda and also effect social and mental status of person. If the man does not follow the rules of taking food and continuously taking virudhahara (unwholesome diet), stops natural urges his Agni (digestive fire) get vitiated and vitiated JathrAgni (digestive fire) is the cause of all diseases ${ }^{1}$. Inspite of mandagni (weak digestive fire) if diet is taken it will not digest properly and causes Grahaniroga (Small intestine disease) ${ }^{2}$. In case of Atisar (diarrhoea) if apathyakarahar (unwholesome diet) taken it causes Agnimandya (suppressed digestive fire), improper digestion, distension of abdomen and vitiates the Grahani (Small intestine) i.e. shasthipittdharakala and causes Grahaniroga (Small intestine disease) ${ }^{3}$. Since Grahaniroga (Small intestine disease) is totally dependent on Agni (digestive fire). Treating the root cause of Grahaniroga (Small intestine disease) is important that is why Lavanbhaskar churna described in Sharangdhar samhita is very useful ${ }^{4}$.

\section{Line of treatment of Grahaniroga (Small intestine disease)}

There are two fundamental element of line of treatment, first one is nidanparivarjan i.e. removal of cause and other one is maintenance of dhatus i.e. dhatusamya. When ama dosa (undigested food) is situated in Grahani (Small intestine), Grahaniroga (Small intestine disease) occurs which has symptoms of excessive salivation, pain in abdomen, anorexia and distension of abdomen, it is called as samagrahani. In samagrahani, vaman (emesis) with Luke warm water or madanphalapippali or sarasapkalka is indicated $^{5}$. In the Grahaniroga (Small intestine disease) Diseases if Aama dosa (undigested food) is deeply situated in Aamasaya (stomach) and pakvasaya (large intestine) then deepan and virechana is applied and if it is situated in the whole body then langhan (fasting) and pachan (digestion) should be given ${ }^{6}$. In Astanghrudaya it is said that when dosas are situated in Grahani it is treated as ajeerna and amadosa is treated as Atisara (diarrhoea) disease $^{7}$. In the Grahani disease if the treatment of Agni (digestive fire) is done it can give the proper relief because Agni (digestive fire) gets vitiated in this disease.

\section{Aims and Objective}

- To see the effect of Lavanbhaskar churna in Grahaniroga (Small intestine disease).

- To study the effective dose of lavanbhaskar churna in Grahaniroga (Small intestine disease).

- To study the details of Grahaniroga (Small intestine disease) and Agni (digestive fire) with Ayurvedic point of views.

- To study the effect of Agni chikitsa (stimulation of digestive fire) in the management of Grahaniroga (Small intestine disease).

\section{MATERIAL AND METHOD \\ Study Design}

A total 15 patient of Grahaniroga (Small intestine disease) were registered for Trial. Present study was open clinical trial at outdoor patient level with appropriate sample. 
Inclusion criteria of patient to Study Group

- Diagnosed Patient of Grahaniroga (Small intestine disease) was selected from the Outdoor patient of the Vidarbha Ayurved Mahavidyalaya, Hospital, Amravati, India after screening them as per Ayurvedic criteria for Grahaniroga (Small intestine disease).

- Patient in the age group between 30 to 70 years of either sex.

Exclusion criteria

- Patient of age less than 30 years and above 70 years.

- Complicated cases like Diabetes, Hypertension, Malignancy and STD.

- Severe systemic diseases, pregnant women.

\section{Selection of Drug, Dose and Duration}

Selected 15 patients received 1 to $3 \mathrm{~g}$ Lavanbhaskara churna with Luke warm water, twice a day for 2 months.

\section{Contents of Lavanbhaskara churna}

Trikatu Pippali (Piper longum), Sunthi (Zinziber officinale) marich (Black pepper), pippalimula (Piper longum root), coriander seed, black cumin, rock salt, tallish patra (Abies webbiana leaves), nagakeshar (Mesua ferrea), amlavetasa (Garcinia pedunculata), tvak and dadimdana (Pomogranate) ${ }^{8}$,

\section{Follow-up of Treatment}

Every patient assessed for any clinical improvement and for adverse effects regularly, follow-up taken at every week for 2 month.

\section{Criteria for Assessment}

After the completion of the treatment, the result was assessed by adopting the following criteria improvement in symptoms of disease on the basis of subjective and objective assessment parameters.

Table 1: Sex wise distribution

\begin{tabular}{|c|c|c|}
\hline Gender & $\begin{array}{c}\text { Number of } \\
\text { Patient }\end{array}$ & Percentage \\
\hline Male & 7 & $46.6 \%$ \\
\hline Female & 8 & $53.33 \%$ \\
\hline Total & 15 & $100 \%$ \\
\hline
\end{tabular}

Table 3: Prakruti wise distribution

\begin{tabular}{|c|c|c|c|}
\hline S No & Prakruti & Patient & Percentage \\
\hline 1 & Vata & 3 & $20 \%$ \\
\hline 2 & Pitta & 0 & 0 \\
\hline 3 & Kapha & 0 & 0 \\
\hline 4 & VP-vatapitta & 5 & $33 \%$ \\
\hline 5 & VK-vatakapha & 2 & $13 \%$ \\
\hline 6 & PK-pittakapha & 4 & $26 \%$ \\
\hline 7 & Tridoshaja & 1 & $6 \%$ \\
\hline
\end{tabular}

\section{Subjective Assessment criteria}

A detailed Performa was prepared for improvement in sign and symptoms in Grahaniroga (Small intestine disease). Patients were examined at every week for the period of 2 month.

- The presence of symptoms of Grahaniroga (Small intestine disease) was recorded as 0 to +4 gradation indicating Nil, Mild, Moderate and severe.

- Assessment of signs and symptoms such as Agnimandya (suppressed digestive fire), Aruchi (loss of taste), Trushna (thirst), Chardi (vomiting), adhmana, Asamyak mal pravrutti (randomly loose or hard stool) was assessed ${ }^{9}$.

\section{Laboratory investigations}

- Haematological investigations- Haemoglobin \%, Total lymphocyte count, Differential lymphocyte count, Erythrocyte sedimentation rate, Serum triglyceride, and Blood sugar (fasting and Postprandial)

- Routine and Microscopic Urine analysis

\section{RESULTS AND DISCUSSION}

It was observed that percentage relief in various symptoms of Grahaniroga (Small intestine disease) was found, for example relief in Aruchi (loss of taste) was $67.64 \%$, in the Agnimandya (suppressed digestive fire) it was $69.23 \%$, in Trushna (thirst) it was $66.66 \%$, in Chardi (vomiting) 70.965 relief and in Adhmana (distension) $58.82 \%$ relief while in case of asamyak mal pravrutti it was $58.62 \%$ relief was observed. In the haematological value it was seen that Lavanbhaskar churna showed effect in the haemoglobin value and increased Red Blood Cells, lowered the total cholesterol, but in the case of blood urea value it is not effective. Seeing the above data it is clear that agni deepan chikitsa (stimulating digestive fire) is highly effective in treatment of Grahani roga.

Table 2: Economic status wise distribution

\begin{tabular}{|c|c|c|}
\hline Economic status & Percentage & $\begin{array}{c}\text { Number of } \\
\text { Patient }\end{array}$ \\
\hline Poor & $53.33 \%$ & 8 \\
\hline Middle class & $40 \%$ & 6 \\
\hline Higher class & $6.66 \%$ & 1 \\
\hline Total & $100 \%$ & 15 \\
\hline
\end{tabular}

Table 4: Age wise distribution

\begin{tabular}{|c|c|c|c|}
\hline S No & Age group & $\begin{array}{c}\text { Number of } \\
\text { patient }\end{array}$ & Percentage \\
\hline 1 & 30 to 40 & 3 & $20 \%$ \\
\hline 2 & 41 to 50 & 7 & $46 \%$ \\
\hline 3 & 51 to 60 & 2 & $13 \%$ \\
\hline 4 & 61 to 70 & 3 & $20 \%$ \\
\hline
\end{tabular}

Table 5: Effect of therapy on symptoms before and after treatment

\begin{tabular}{|c|c|c|c|c|}
\hline S No & Symptoms & BT & AT & \% Relief \\
\hline 1 & Aruchi (loss of taste) & 34 & 11 & $67.64 \%$ \\
\hline 2 & Agnimandya (suppressed digestive fire) & 26 & 8 & $69.23 \%$ \\
\hline 3 & Trushna (thirst) & 30 & 10 & $66.66 \%$ \\
\hline 4 & Chardi (vomiting) & 31 & 9 & $70.96 \%$ \\
\hline 5 & Adhmana (distension) & 34 & 14 & $58.82 \%$ \\
\hline 6 & Asamyak mal pravrutti(loose and hard stool) & 29 & 12 & $58.62 \%$ \\
\hline
\end{tabular}

Table 6: Statically analysis of symptoms by pair $t$ test 


\begin{tabular}{|c|c|c|c|c|c|}
\hline S No. & Symptoms & Mean & SD & SED & p value \\
\hline 1 & Aruchi (loss of taste) & 1.80 & 0.4140 & 0.1069 & $<0.0001$ \\
\hline 2 & Agnimandya (suppressed digestive fire) & 1.33 & 0.4888 & 0.1260 & $<0.0001$ \\
\hline 3 & Trushna (thirst) & 1.60 & 0.7368 & 0.1902 & $<0.0001$ \\
\hline 4 & Chardi (vomiting) & 1.60 & 0.5071 & 0.1309 & $<0.0001$ \\
\hline 5 & Adhmana (distension) & 1.46 & 0.6399 & 0.1632 & $<0.0001$ \\
\hline 6 & Asamyakmalpravrutti (loose and hard stool) & 1.26 & 0.4577 & 0.1182 & $<0.0001$ \\
\hline
\end{tabular}

Table 7: Effect of drug on Haematological values

\begin{tabular}{|c|c|c|c|c|c|}
\hline S.NO & Haematological value & Mean & SD & SED & p value \\
\hline 1 & Haemoglobin & -1.073 & 0.8852 & 0.2285 & $<0.0001$ \\
\hline 2 & Red Blood Cell & -0.6067 & 0.4743 & 0.1225 & $<0.0001$ \\
\hline 3 & ESR & 0.3333 & 1.447 & 0.3737 & $<0.5781$ \\
\hline 4 & Albumin & 0.3333 & 1.447 & 0.3737 & $<0.5781$ \\
\hline 5 & Blood urea & 0.000 & 0.3780 & 0.09759 & $>0.9999$ \\
\hline 6 & Serum triglyceride & 28.933 & 31.956 & 8.287 & $<0.0001$ \\
\hline 7 & Blood Sugar fasting & -3.467 & 9.342 & 2.412 & $<0.2524$ \\
\hline 8 & Blood Sugar -postprandial & -5.600 & 14.106 & 3.642 & $<0.1514$ \\
\hline
\end{tabular}

Table 8: Total effect of therapy

\begin{tabular}{|c|c|c|}
\hline Effect & Number of patients & Percentage \\
\hline Markedly improved & 9 & $60 \%$ \\
\hline Moderately improved & 3 & $20 \%$ \\
\hline Mild relief & 2 & $13.33 \%$ \\
\hline No relief & 1 & $6.66 \%$ \\
\hline
\end{tabular}

It may be either due to cumulative effect of drug or individual contents of the drug, because it is seen that some haematological values like haemoglobin, Red Blood Cells, Total cholesterol changes while in case of blood urea no effect is seen. In the above observation it is seen that $p$ value is $<0.0001$ which indicates that the effect of drug is extremely significant on the diseases. In this study the effect of Lavanbhaskar churna on Grahaniroga (Small intestine disease) was due to drugs properties like Katu, Tikta, Kashaya, lavan, and amla rasa, Ushna Virya and drugs having Deepan (stimulating digestive fire), Pachan (digestion of food) and grahi (binding) properties.

\section{CONCLUSION}

The above study showed that nine patients got markedly symptomatic improvement while three got moderately effect, while two patients got mild relief in symptoms, one patient did not get relief. This indicates that lavanbhaskar churna as a agnideepan (stimulating digestion) chikitsa is highly effective in Grahaniroga (Small intestine disease). The present clinical trial is a limited resource on a very small number of patients. It is proposed that the same project can be undertaken on a large series of patients with more scientific parameters for further research.

\section{REFERENCES}

1. Shastri Pandit Kashinath and Dr Chaturvedi Gorakha Natha. Editor Charak Samhita of Agnivesa elaborated Vidyotini Hindi commentary, Part II Published by Chaukhambha Bharti Academy, Varanasi, India. Reprint 1994, Chikitsa sthanam Chapter 15 Gharhanichikitsa, Verse71, p. 463.
2. Madhavakara, Madhavanidan, Madhukosh Hindi Translation by Upadhay Yadunandan Published by Chaukhamba Prakashana, Varanasi, Edition $19^{\text {th }}$ (1990), Chapter 4, Verse 1, p. 162.

3. Dr Shastri Ambikaprasad. Susruta Samhita edited with Ayurveda Tattva Sandipika Hindi commentary, Uttarsthana, Published by Chaukhambha Bharti Academy, Varanasi, India. Edition $8^{\text {th }}$ (1993), Chapter 40, Atisar pratishedha, Versa 166,167, p. 237.

4. Sarangadharacharya, Sarangdhar samhita, Hindi Translation by Parsuram Vidyasagar Shastri. Published by Chaukhamba Prakashana, Varanasi, Edition $3^{\text {rd }}(1983)$, Madhyama khanda Chapter 6, Verse 145, 146, p. 194.

5. Shastri Pandit Kashinath and Dr Chaturvedi Gorakha Natha. Editor Charak Samhita of Agnivesa elaborated Vidyotini Hindi commentary, Part II Published by Chaukhambha Bharti Academy, Varanasi, India. Reprint 1994, Chikitsa Sthanam Chapter 15 Gharhanichikitsa,Verse 74, p. 464.

6. Shastri Pandit Kashinath and Dr Chaturvedi Gorakha Natha. Editor Charak Samhita of Agnivesa elaborated Vidyotini Hindi commentary, Part II Published by Chaukhambha Bharti Academy, Varanasi, India. Reprint 1994, Chikitsa sthanam Chapter 15 Gharhanichikitsa, Verse 75, p. 464.

7. Upadhay Yadunandan. Editor, Ashtang Hrudaya, Published by Chaukhambha Bharti Academy, Varanasi, India. Edition $11^{\text {th }} 1993$, Chikitsa Sthana, Chapter 10, Verse 1, p. 361.

8. Sarangadhara. Sarangdharsamhita Hindi Translation by Parsuram Vidyasagar Shastri Published by Chaukhamba Prakashana, Varanasi, Edition $3^{\text {rd }}(1983)$, Madhyama khanda ,Chapter 6 , Verse 140,141,142,143, p. 194.

9. Pandit Shastri Kashinath and Dr Chaturvedi Gorakha Natha. Editor Charak Samhita of Agnivesa elaborated Vidyotini Hindi commentary, Part II Published by Chaukhambha Bharti Academy, Varanasi, India. Reprint 1994, Chikitsa sthanam Chapter 15 Gharhanichikitsa, Verse 52, 53, 54, p. 461, 462.

\section{Cite this article as:}

Wange Mangala Dilip. Importance of agni (digestive fire) in the management of Grahani disease with special reference to Lavanbhaskarchurna in grahaniroga (small intestine disease). Int. J. Res. Ayurveda Pharm. 2013;4(4):583-585 http://dx.doi.org/10.7897/2277$\underline{4343.04426}$ 